\title{
BIBLIOMETRIC ANALYSIS OF FOREIGN DIRECT INVESTMENT AND ECONOMIC GROWTH RELATIONSHIP. A RESEARCH AGENDA
}

\author{
Claudiu CICEA $\mathbb{1}^{*}$, Corina MARINESCU(D) \\ Faculty of Management, Bucharest University of Economic Studies, Bucharest, Romania \\ Received 17 June 2020; accepted 18 November 2020
}

\begin{abstract}
The relationship between foreign direct investment and economic growth is a relationship that has long been studied in the economic literature, of particular importance for the economic and social development of any nation. The main objective of this paper is to analyze the scientific output in this scientific area, based on a bibliometric analysis, in order to identify some trends and to explain some phenomena within the economic reality.

The paper analyzed 2281 documents from the Scopus database, using tools provided by the aforementioned database, VOSViewer and Citespace software. The analysis was carried out on several levels: typology of information dissemination, thematic area of publications, temporal/geographical distribution of documents and their scientific content.

Among the findings authors can mention that the connection between foreign direct investment and economic growth is very strong (according to the cluster analysis in VOSViewer); consequently, the focus of the authors migrated from general economic aspects of the relationship to the elements of ecology and environmental protection. Going deeper with the analysis, conducting two parallel analysis of the papers with highest citation burst and keywords with highest citation strength values, some interesting trends were found in the relationship between foreign direct investment and economic growth.
\end{abstract}

Keywords: foreign direct investment (FDI), economic growth, bibliometric research, text mining, VOSViewer, Citespace, scientific knowledge.

JEL Classification: F21, F43, O10, O47.

\section{Introduction}

Over the years, experts studied the connection between investment and economic growth, in different countries or economies. Moreover, many authors have stated that investments are the engine of any economic growth (Liesbeth et al., 2009) as well as that of human development (Torabi, 2015), the means by which an increase in wealth can be achieved in any national economy or global, in any human community. Usually, economic growth is

*Corresponding author. E-mail: claudiu.cicea@man.ase.ro

Copyright (c) 2021 The Author(s). Published by Vilnius Gediminas Technical University

This is an Open Access article distributed under the terms of the Creative Commons Attribution License (http://creativecommons. org/licenses/by/4.0/), which permits unrestricted use, distribution, and reproduction in any medium, provided the original author and source are credited. 
measured through the increase of gross domestic product in two consecutive periods, and the main effect is the economic development which can be measured through quality of life and living standards - total average monthly wages by household, number of doctors per 1000 inhabitants, employment rate etc. (Botha et al., 2020).

Going further with the analysis, it should be mentioned that the role of investments in economic growth is not limited only to an increase in aggregate demand, but also to the effect of multiplication (the multiplier of investments). In other words, an injection of investment into an economy will cause the companies that benefit from it (large companies, corporations but also SMEs) to record higher sales and make additional profits; as a result, they will be more willing to invest in turn, thus recording a propagated (multiplied) effect of the initial investment (Keynes, 1936). Obviously, since the discovery of the multiplication effect (1936), there have been numerous approaches from different points of view that have analyzed the problem of the effect of multiplying the investments (Hochstein, 2019; Zhao \& Gao, 2005; Obsiannikova et al., 2017).

Further analyzing, the authors can say that foreign direct investments have a decisive influence on the economic development of any nation, being a condition (prerequisites) to attract new investors in the economy or to improve the quality of human resources (Simionescu \& Naros, 2019). For certain well-defined geographical areas (e.g. European Union), these foreign direct investments can also take the form of the structural funds (or communitarian funds), available to the member countries, representing a decisive factor for the economic growth at both macroeconomic and microeconomic level (Cicea et al., 2019). Also, there is a well-known fact that there is a string econometric connection between foreign direct investment and economic growth, which was studied by many authors in the past (Ali et al, 2018; Chaudhary, 2018; Hagan \& Amoah, 2020).

Moreover, there is an ambivalent relationship between foreign direct investment and economic growth (Mawugnon \& Qiang, 2011). On the one hand, foreign direct investments, through the creation of new jobs and the added value, bring fundamentally contribution to economic growth; on the other hand, the economic growth (materialized in the growth of the gross domestic product) provides the necessary conditions for the realization of the foreign direct investments in any economy.

Undoubtedly, economic growth has been studied in relation to other decisive factors, such as public spending (Artinok \& Arslan, 2020), natural resources (Topcu et al., 2020), energy consumption (Le et al., 2020), the level of innovation (Dekker, 2020), entrepreneurial ventures (Vekic et al., 2020) etc. However, the vast majority of specialists appreciate the crucial role of FDI for economic growth. Moreover, in the context of the unprecedented medical crisis (generated by the SARS-COV2 pandemic), the relationship between FDI and economic growth has become a central point of analysis for experts, in order to initiate economic recovery measures (Osei \& Kim, 2020; Billas, 2020; Dong \& Fan, 2020).

The present work continues previous author's research, based on bibliometric approach using VOSViewer software (Marinescu et al., 2019; Cicea, 2020) and other papers in the bibliometric area (Olczyk, 2016; Diaconeasa et al., 2019).

The objective of this paper is to study the relationship between foreign direct investment and economic growth (based on a text mining approach), in order to discover patterns, to 
explain developments/changes in vision over time as well as to identify potential trends in the future. In order to achieve this objective, two directions of action have been defined, namely: the inventory of scientific production in this field, based on successive refineries starting from prestigious databases; the use of specific analysis tools and specialized software, in order to capture the fundamental elements of the relationship between foreign direct investment and economic growth.

The paper is structured as follows: the next section is dedicated to a radiography of the literature, to see how the relationship between the two variables has been analyzed over time. At the same time, based on this section, the importance of studying the relationship between foreign direct investment and economic growth is revealed. The next section ("Research method") presents, from the theoretical point of view, which are the main steps of the research methodology, with a short description of each of them. Section "Results and discussion" presents the findings of the analysis, taking into account several dimensions (typology of the dissemination, thematic area, temporal and geographical dimension, scientific content). The last section ("Conclusions") provides a brief summary of the findings, practical implications, limitations of the research paper and direction for a potential future research.

\section{Literature review}

Over time, many authors have analyzed the issue of foreign direct investment and economic growth, from different points of view. Thus, some authors have studied this relationship in close connection with financial development (Hermes \& Lensink, 2003); others pointed out that economic growth based on direct investments is achieved through technology transfer (Borensztein et al., 1998), while other authors have stated that not only foreign direct investments influence economic growth, but also a number of others factors such as exports, imports, inflation rate, etc. (from De Andrade \& Quing, 2015). Also, over time, the specialists have developed different indicators for evaluating direct investments in different fields of activity: in tourism (Nestico \& Maselli, 2020), in agriculture (Cicea et al., 2010), in construction and buildings (Dylewski \& Adamczyk, 2012), in mining and quarrying (Lacko et al., 2017) etc.

Analyzing a short the literature review for the last 30 years, we can identify some suggestive studies referring to the relationship between "economic growth" and "foreign direct investment". In the appendix we will present a short history with important articles in the field (grouped by continents, according to the country of the corresponding author), together with a brief description for each of them (for this purpose, we used Scopus and Web of Science databases).

Starting from the previous studies that analyzed the relationship between foreign direct investment and economic growth, the authors propose in this paper to realize a research agenda in this field, based on a bibliometric approach.

Regarding the originality of this paper, it is useful to specify that, according to the authors knowledge, this is the first study that analyzes the link between "foreign direct investment" and "economic growth" based on a text mining approach, using two specialized software at the same time (VosViewer and Citespace). As a proof in this sense, after a complex query 
of the SCOPUS database (using key phrases "FDI", “economic growth", "text mining" etc.), only 3 articles (out of more than 70 millions documents) that corresponded to the search criteria resulted (Park, 2018; Kumari \& Kumar Sharma, 2017; Bruhn et al., 2016), but none of them addressed all aspects of this research at the same time (either focusing only on the relationship between "foreign direct investment" and "economic growth", without having a bibliometric approach; or using the text mining technique, but focusing on infrastructure instead of foreign direct investments etc.).

\section{Research method}

The research methodology involves a text mining analysis of the literature in the field, in order to identify possible patterns, correlations and links between the two previously mentioned phrases ("foreign direct investment" and "economic growth"). At the same time, the methodology also includes an analysis of the temporal and geographical distribution of the documents in this scientific area.

In detail, the analysis involves the identification of scientific knowledge, in a particular scientific area and its analysis based on relevant information (belonging to the authors, geographical and temporal distribution, keywords, topic of the journals in which it was published scientific production etc.).

The fundamental purpose of the analysis is to study certain patterns / models registered in the past in order to identify potential trends in the future and to make comparisons with phenomena / processes / events in contemporary economic and social reality.

The research methodology involves the following stages:

1. Identification of scientific production in the area

In the scientific literature there is a multitude of databases with scientific knowledge, which are worldwide recognized. A brief characterization of these databases is presented in the Table 1 (Paperpile, n.d.).

Table 1. Most important scientific databases (source: Paperpile, n.d.)

\begin{tabular}{|c|l|c|l|l|}
\hline No. & Name of database & $\begin{array}{c}\text { Number of items } \\
\text { (aprox.) }\end{array}$ & \multicolumn{1}{|c|}{ Discipline } & \multicolumn{1}{|c|}{ Provider } \\
\hline 1. & Web of Science & 100 millions & Multidisciplinary & Clarivate \\
\hline 2. & Scopus & 71 millions & Multidisciplinary & Elsevier \\
\hline 3. & PubMed & 30 millions & $\begin{array}{l}\text { Medicine, } \\
\text { Biological Sciences }\end{array}$ & $\begin{array}{l}\text { National Institute of } \\
\text { Health }\end{array}$ \\
\hline 4. & Science Direct & 16 millions & Multidisciplinary & Elsevier \\
\hline 5. & Jstor & 12 millions & Multidisciplinary & Ithaka \\
\hline 6. & IEEE Xplore & 5 millions & Engineering & $\begin{array}{l}\text { Institute of Electrical and } \\
\text { Electronics Engineers }\end{array}$ \\
\hline 7. & $\begin{array}{l}\text { Directory of Open } \\
\text { Access Journals }\end{array}$ & 4.3 millions & Multidisciplinary & DOAJ \\
\hline 8. & ERIC & 1.3 millions & Education science & $\begin{array}{l}\text { U.S. Department of } \\
\text { Education }\end{array}$ \\
\hline
\end{tabular}


Given the specificity of the relationship between economic growth and foreign direct investment, it is clear that the research will have to focus on multidisciplinary databases (eliminating those databases such as IEEE Xplore). As can be seen from the Table 1, the main multidisciplinary databases are Web of Science (WoS) and Scopus. Taking into account that many journals are indexed in both databases, it is not justified to use them simultaneously, as it would create unwanted redundancy.

A simple search of the two databases after the terms "foreign direct investment" and "economic growth" returned more results in the Scopus database than in the Web of Science (WoS). As a result, the present study will continue to use the Scopus database.

By simultaneously querying the Scopus database after two terms (on the one hand "FDI" and "foreign direct investment", and on the other hand "economic growth"), the authors select a number of 2684 documents (containing those phrases in the title, in abstract or in keywords).

After successive refinements (elimination of the year 2020, being an incomplete year; taking into account only those publications such as "article", "conference paper" and "book chapter"; elimination of all documents that are not written in English) a number of 2289 of documents remained.

\section{Analysis of the scientific production}

The analysis is based on the investigative tools provided by the Scopus database as well as the facilities provided by the VOSViewer software (van Eck \& Waltman, 2011).

Thus, the typology of the dissemination mode for the scientific knowledge, the thematic area of the publications, the temporal and geographical distribution of the documents and the analysis of the scientific content will be analyzed (with the identification and analysis of the frequency of occurrence for different topics). Using Citespace software the analysis can go deeper with scientific content analysis and the present study can identify some documents considered "milestones" for the relation between "foreign direct investment" and "economic growth"; also, the authors will identify the main trends in this area, in order to illustrate the evolution over time (Chen, 2006).

\section{Results and discussion}

As mentioned above, the basis of the analysis is composed by 2289 documents containing the phrases "foreign direct investment" and "economic growth" in their title, abstract or keywords.

1. Analysis of the typology of the dissemination for scientific knowledge

The Scopus database offers the possibility to analyze which is the most widely used means of disseminating information. Taking into account the total number of papers (2289 documents) that contain phrases "foreign direct investment" and "economic growth" in their title, abstract or keywords, the present study found an unequal distribution of the type of document used for disseminating the information, according to the graphic from Figure 1.

Analyzing this graph the authors noticed, that the main document used for disseminating scientific information is the "article" (84.0\%, respectively 1922), followed by the "book chapter" $(8.4 \%$, respectively 192$)$ and conference papers $(7.6 \%, 174)$. This distribution on the 


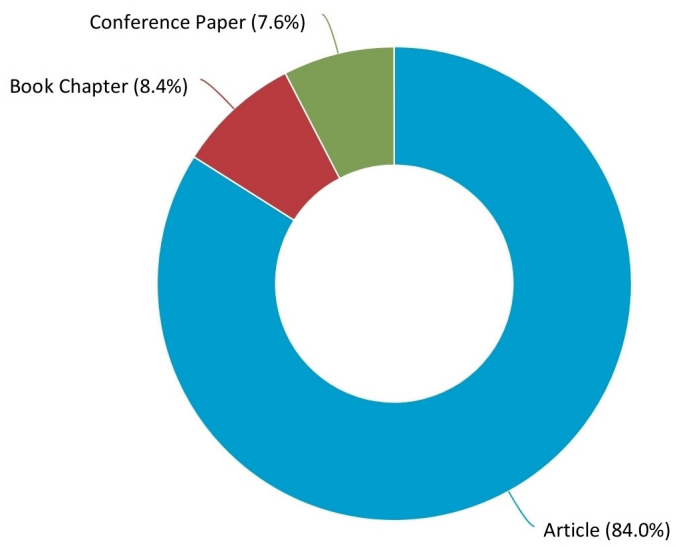

Figure 1. Documents by types (source: Scopus database)

three types of documents is almost the same with the distribution of the documents within the Scopus database, for the whole "Economics, Econometrics and Finance" and "Business, Management and Accounting” areas (1708957 articles, 84.34\%; 167268 book chapters, 8.25\%; 149987 conference proceedings, 7.4\%).

In total, these three types of publication cover $85.3 \%$ (2289 documents) of the total of 2684 documents (including also other types of documents such as review, business articles, economic survey etc.), which justifies their inclusion in the analysis, apart from the other forms.

2. Analysis of the thematic area of the publications

The Scopus database has several predefined thematic areas, depending on the scientific fields ("computer science", "environmental science", "arts and humanities", "mathematics", "agricultural and biological sciences", "medicine', etc.).

The situation of the distribution of the database with the 2289 documents by thematic areas is presented in the Figure 2.

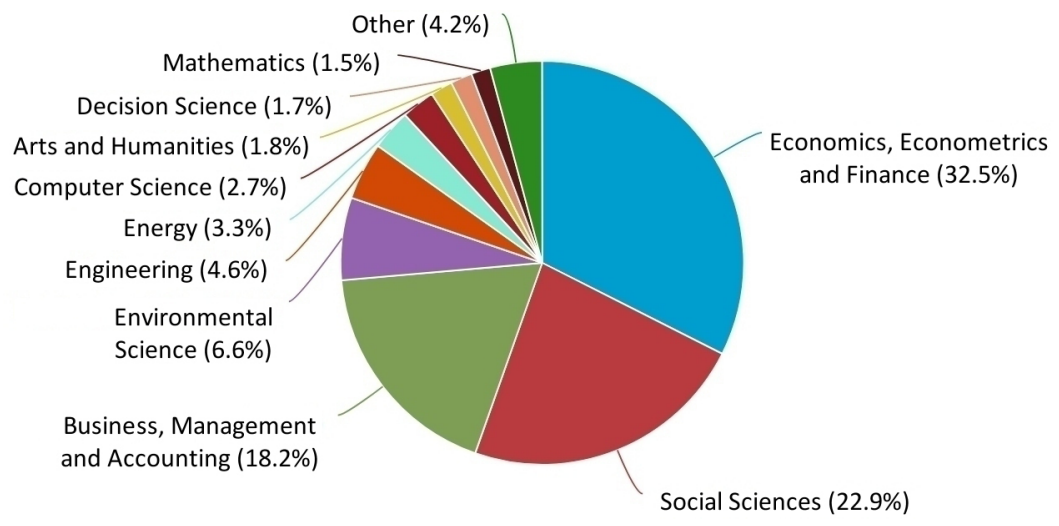

Figure 2. Documents by subject area (source: Scopus database) 
According to this graph, it can be observed that the main subject areas are "Economics, Econometrics and Finance" (with 1218 documents), "Social sciences" (with 861 documents) and "Business Management and Accounting" (with 684 documents). The 4th place ("Environmental sciences"), with 248 documents, can be found at a great distance.

In total, the first 3 subject areas count for almost $3 / 4$ (73.6\%) of the total number of documents.

3. Temporal and geographical analysis

One of the most suggestive analyzes concerns the temporal evolution of scientific knowledge, presented in the Figure 3.

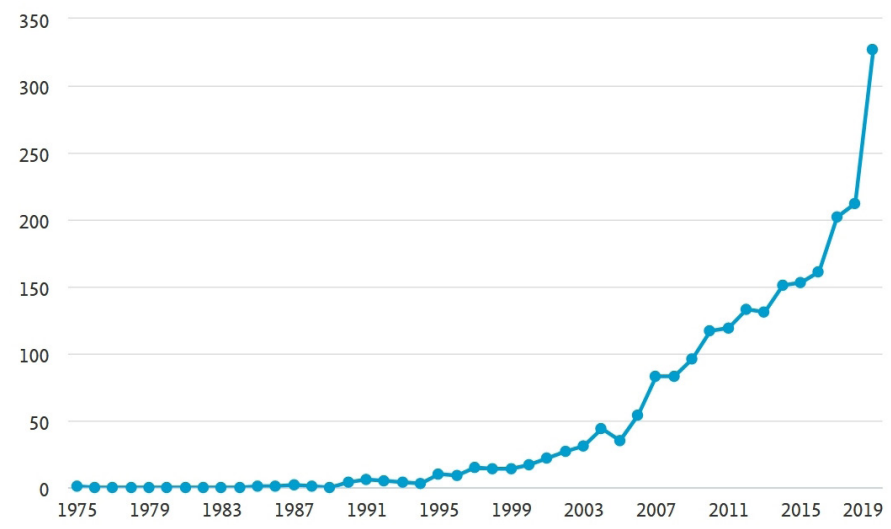

Figure 3. Documents per year (source: Scopus database)

As can be seen, the relationship between "economic growth" and "foreign direct investment" has begun to be analyzed since 1985, when the first article was registered. However, the inclination of the specialists to study this field has steadily increased since the beginning of this millennium (reaching from 17 documents at the level of year 2000 to 324 documents at the level of year 2019).

Regarding the geographical distribution (by continents) of scientific production in the field of the relationship between "economic growth" and "foreign direct investment", it is very useful to present in the Table 2 the first 20 countries (according to their total number of articles, conference proceedings or book chapters, in the Scopus database):

Making a comparative analysis through continents regarding the scientific production, we can observe a growing interest of Asian researchers to study the relationship between "economic growth" and "foreign direct investment" (the Asia continent leads by far the top, with a total number of 907 documents, more than double the second place which belong to Europe with 407 documents). Moreover, specialists on this continent point a special emphasis on the econometric perspective for analysis, unlike other specialists on other continents.

Another conclusion that can be deduced (reached by most authors, regardless of the continent) is that economic growth does not depend decisively on foreign direct investment, but also on other factors (e.g. trade openness).

Finally, the particularity of the research on the North American continent should be highlighted, which is manifested by the fact that the vast majority of studies do not consider 
Table 2. Top 20 countries according to their scientific production (source: Scopus)

\begin{tabular}{|c|c|c|c|c|c|c|c|c|c|}
\hline Conti- & \multicolumn{9}{|c|}{ Country (place in top 20) } \\
\hline \multirow[t]{2}{*}{ Asia } & $\begin{array}{c}\text { China } \\
(2)\end{array}$ & $\begin{array}{l}\text { Malay- } \\
\text { sia (4) }\end{array}$ & $\begin{array}{l}\text { India } \\
(5)\end{array}$ & $\begin{array}{c}\text { Pakistan } \\
(7)\end{array}$ & $\begin{array}{c}\text { Japan } \\
(15)\end{array}$ & $\begin{array}{c}\text { Taiwan } \\
(17)\end{array}$ & $\begin{array}{c}\text { South } \\
\text { Korea } \\
(18)\end{array}$ & $\begin{array}{l}\text { Iran } \\
(19)\end{array}$ & $\begin{array}{c}\text { Thailand } \\
(20)\end{array}$ \\
\hline & 303 & 160 & 142 & 106 & 47 & 42 & 38 & 35 & 34 \\
\hline Total & \multicolumn{9}{|c|}{907} \\
\hline \multirow[t]{2}{*}{ Europe } & \multicolumn{2}{|c|}{ UK (3) } & \multicolumn{2}{|c|}{ Turkey (9) } & \multicolumn{2}{|c|}{ France (11) } & \multicolumn{2}{|c|}{ Romania (13) } & $\begin{array}{c}\text { Germany } \\
(14)\end{array}$ \\
\hline & \multicolumn{2}{|c|}{184} & \multicolumn{2}{|c|}{72} & \multicolumn{2}{|c|}{57} & \multicolumn{2}{|c|}{53} & 40 \\
\hline Total & \multicolumn{9}{|c|}{406} \\
\hline \multirow{2}{*}{ America } & \multicolumn{4}{|c|}{ USA (1) } & \multicolumn{5}{|c|}{ Canada (12) } \\
\hline & \multicolumn{4}{|c|}{371} & \multicolumn{5}{|c|}{55} \\
\hline Total & \multicolumn{9}{|c|}{426} \\
\hline \multirow{2}{*}{ Africa } & \multicolumn{3}{|c|}{ South Africa (8) } & \multicolumn{3}{|c|}{ Nigeria (10) } & \multicolumn{3}{|c|}{ Tunisia (16) } \\
\hline & \multicolumn{3}{|c|}{75} & \multicolumn{3}{|c|}{59} & \multicolumn{3}{|c|}{44} \\
\hline Total & \multicolumn{9}{|c|}{178} \\
\hline \multirow{2}{*}{ Australia } & \multicolumn{9}{|c|}{ Australia (6) } \\
\hline & \multicolumn{9}{|c|}{112} \\
\hline Total & \multicolumn{9}{|c|}{112} \\
\hline
\end{tabular}

the geographical area of North America for the conducted analysis, but other areas (e.g. Africa, Kuwait, Bangladesh, etc.). Also, even if United States of America is the number one country according to the number of documents, the America continent took the $3^{\text {rd }}$ place (due to poor ranking of Canada).

\section{Scientific content analysis}

The beginning of this analysis was performed using VOSViewer software (Version 1.6.13 (van Eck \& Waltman, 2019)), which can create an inventory of keywords, authors, citations, etc., identifying correlations or suggestive links between them. Specifically, VOSViewer's internal analysis comprises 4 stages (van Eck \& Waltman, 2011):

1) Identification of all the phrases in the text (the phrase means one or more adjacent words, of which at least one is substantive);

2) Selecting those significant phrases, according to its own algorithm, based on their frequency of occurrence within the analyzed text;

3) Construction of maps and clusters with the identified syntagms;

4) Visualization of the created maps and clusters.

It should be noted that in this paper were analyzed the titles, abstracts and keywords generated from the Scopus database. Using VOSViewer software, the situation of the keywords resulted, ordered according to the frequency of occurrence is presented in the Table 3. 
Table 3. Keywords with a minimum frequency of 100 (source: Autor analysis, based on VOSViewer)

\begin{tabular}{|c|l|c|}
\hline No. & \multicolumn{1}{|c|}{ Keyword } & Frequency \\
\hline 1. & Economic growth (including economic growths) & 1358 \\
\hline 2. & Foreign direct investment (foreign direct investments, FDI) & 1607 \\
\hline 3. & China & 242 \\
\hline 4. & Economic development & 210 \\
\hline 5. & Investments & 204 \\
\hline 6. & Economics & 193 \\
\hline 7. & Panel data & 153 \\
\hline 8. & Asia & 119 \\
\hline 9. & Capital flow & 115 \\
\hline 10 & International trade & 109 \\
\hline 11. & Investment & 108 \\
\hline 12. & Eurasia & 105 \\
\hline 13. & Gross domestic product & 105 \\
\hline 14. & Economic analysis & 100 \\
\hline 15. & Developing world & 100 \\
\hline
\end{tabular}

Going further with the analysis, 4 clusters can be identified whose graphical representation is shown in the Figure 4.

Analyzing the Figure 4, we can observe that there are 2 clusters (in red and blue) which belongs to the economic area, as long as they contain economic keywords such as "foreign direct investment", "economic growth", "economic integration", "economic analysis", "developing countries", "capital flow", "productivity" etc. The small difference between them is that the first one (in red) contains some econometrics issues (keywords such as "econometrics", "numerical model", "panel data").

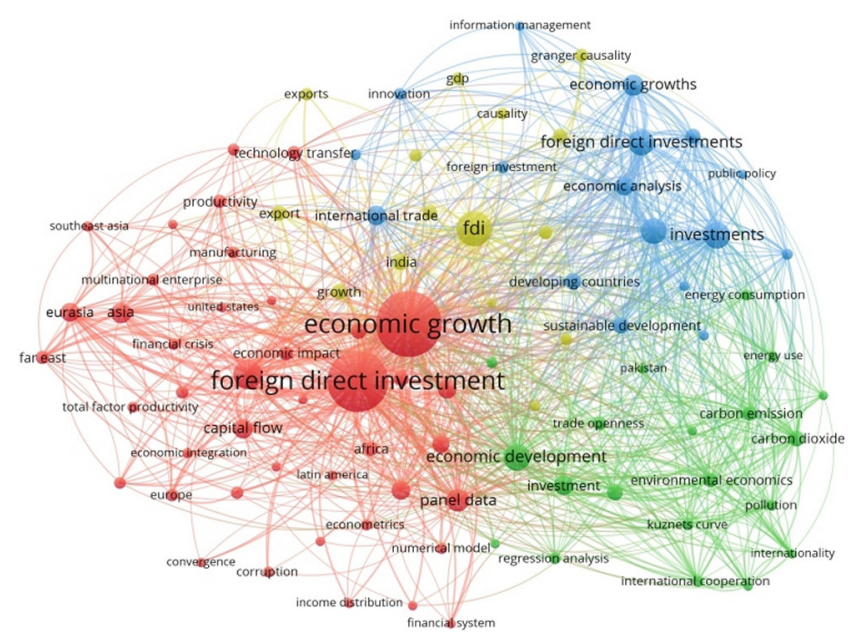

Figure 4. Keywords grouped by clusters (source: Scopus, using VOSViewer) 
The third cluster (the green one), considers the ecological and environmental protection issues, including keywords such as "environmental economics", "CO2 emissions", "pollution", etc. Finally, the 4 th cluster (the yellow one) mainly refers to the causality aspects of the analysis, including keywords such as "granger causality", "cointegration analysis", "causality" etc.

VOSViewer offers the possibility of analyzing the evolution over time of the analyzed keywords, in order to highlight possible patterns. This evolution is shown in the Figure 5.

It is not an easy task to interpret the figure, especially because the trend in scientific research (in every branch of science) is a fluid concept, which does not register sudden changes from one year to another (sometimes, those changes appear in a decade or more). Nevertheless, as far as we can see, at the beginning of the millennium (the year 2000) the focus was placed on economic aspects (frequently keywords such as "multinational enterprise", "economic integration", "Asia", "national economy"); at the level of year 2010, the researchers focused on econometric aspects of the analysis for the relationship between "foreign direct investment" and "econometric growth" (keywords such as "econometrics", "panel data", "numerical model", etc.).

As we approach the present time, the focus of the articles was on the ecological and environmental protection of the relationship between "foreign direct investment" and "economic growth" (with keywords such as "pollution", "carbon emission”, "environmental” etc.).

As the authors mention in the research methodology, the research will go deeper, trying to find out those papers considered "milestones" for the relations between "foreign direct investment" and "economic growth" within the economic literature. From this point of view, papers with a citation bursts over time are presented in the Figure 6.

Analyzing the Figure 6, the present study can identify some interesting facts.

First of all, it is obvious that no matter the period of time, almost all the authors focused on econometric issues regarding the relationship between "foreign direct investment" and "economic growth" (in other words, the econometric perspective represents a constant over the entire period of time). Indeed, Balasubramany V. N. in 1996 ("How does foreign direct

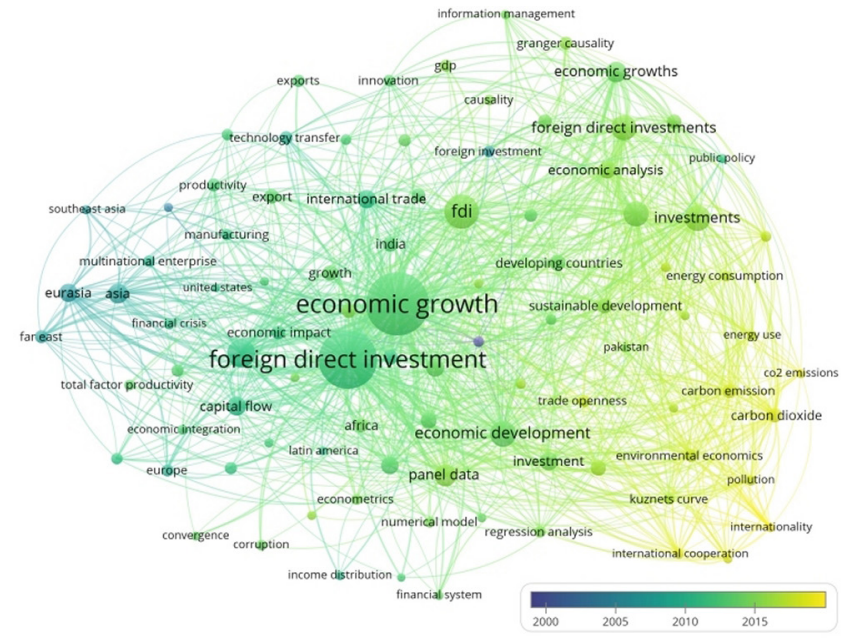

Figure 5. Evolution of keywords over time (source: Scopus, using VOSViewer) 


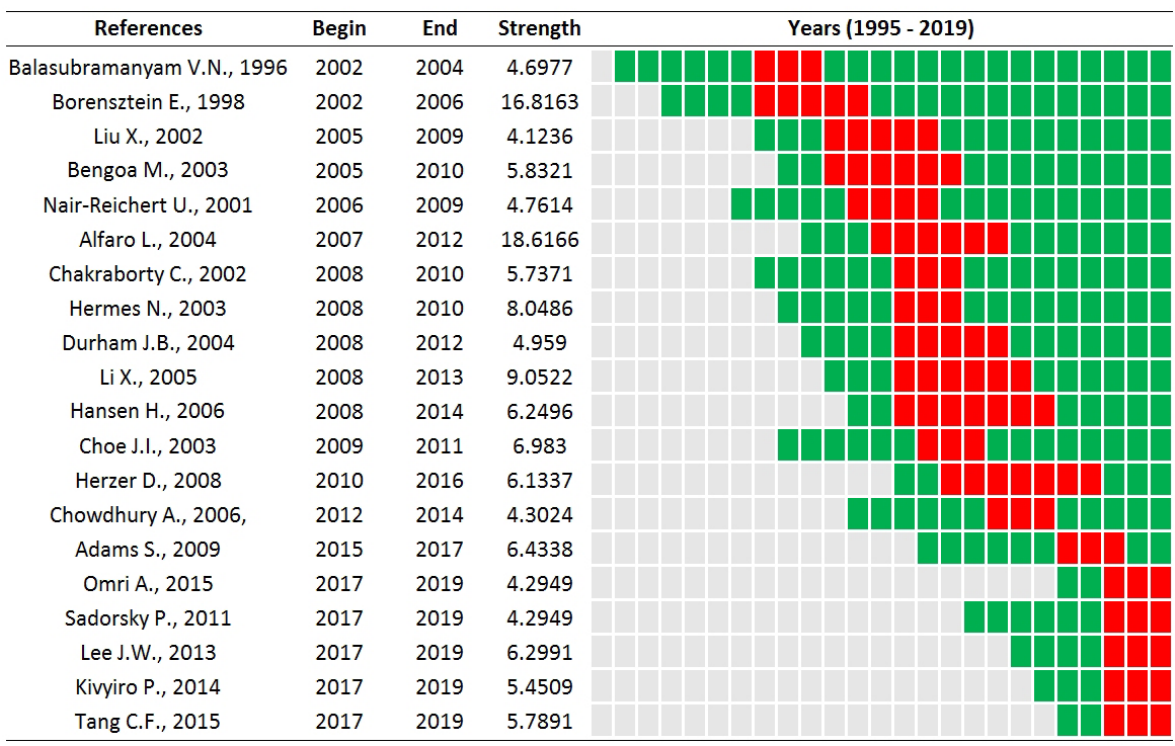

Figure 6. Top articles with citation burst between 1995-2019

(source: Scopus, using Citespace, version 5.7.R2 (Chen, 2020))

investment affect economic growth") tests different hypothesis regarding beneficial effects of foreign direct investment using cross-section data from 46 developing countries. Later, in 2005, Li X. ("Foreign Direct Investment and Economic Growth: An Increasingly Endogenous Relationship") use single and simultaneous equation system techniques on a panel data for 84 countries to study the effect of foreign direct investment over the economic growth, between 1970-1999. Close to the present moment (2009), Adams S. ("Foreign Direct investment, domestic investment, and economic growth in Sub-Saharan Africa") studied the influence of foreign direct investment and domestic investment over the economic growth, using two basic regressions.

Secondly, there is a slightly changes in the topic, over time. To be more specific, if before 2000 the main focus was on the relationship between those two issues, in the last period of time (especially, after 2010) the authors introduce a special attention for the environmental issues, such as the reduction of pollution, energy consumption, environmental protection, sustainable development etc. In this regard, the present study can mention papers like "The contribution of foreign direct investment to clean energy use, carbon emissions and economic growth" (Lee, 2013), "Carbon dioxide emissions, energy consumption, economic growth, and foreign direct investment: Causality analysis for Sub-Saharan Africa” (Kivyiro \& Arminen, 2014), or "The impact of energy consumption, income and foreign direct investment on carbon dioxide emissions in Vietnam" (Tang \& Tan, 2015). Somehow, this change in topic over time (discovered using Citespace) confirms what the authors of this research already discovered with WOSviewer, in the cluster analysis.

Finally, the most important papers in the field (among all top 20 presented in Figure 6 which are considered "milestones" within the total numbers of 2289 papers) are "FDI and 
economic growth: the role of local financial markets" (Alfaro et al., 2004) and "How does foreign direct investment affect economic growth?” (Borensztein et al., 1998). Both of those two papers have very high values for the citation burst strength (18.6166, respectively 16.8163), which indicate that these two papers have a great influence over the literature review in the field of the relationship between foreign direct investment and economic growth. Furthermore, those two papers have a long duration of their citation burst (6 years for the first one, 5 years for the second one).

In order to visualize better the dynamic of the scientific research in the field, the authors consider useful to extract the keyword burst. This information, divided in 3 periods of time, is presented in the Figure 7.

Analysing those 3 periods from Figure 7, the present study can identify the dynamics in the field of the relationship between foreign direct investment and economic growth. In this regard, for the first period (between 1990 and 1999), the authors focused on aspects referring to the national economies when analysing relationship between the 2 concepts (keywords like "developing countries", "trade policy", "technology transfer", "Asia" or "China”). In the second period of time (between 2000 and 2009), the attention was focused on issues referring to the globalization (keywords such "multinational enterprise", "Eurasia", "Europe", "North America") and economic crisis from the end of that period ("financial crisis"). Finally, the last period of time (between 2010 and 2019) we can notice keywords like "causality", "cointegration analysis", "Granger causality", "GDP" which appear more frequently; this can indicate that the authors emphasize the econometric perspective between the foreign direct investment and economic growth.

If we are looking to the top keywords with the highest strength of citation burst, we will discover that the first 4 of them are "Eurasia", "Asia", "far east" (with the strength value of 48.3382, 35.9679 and 21.8197 respectively). Together with another important keyword

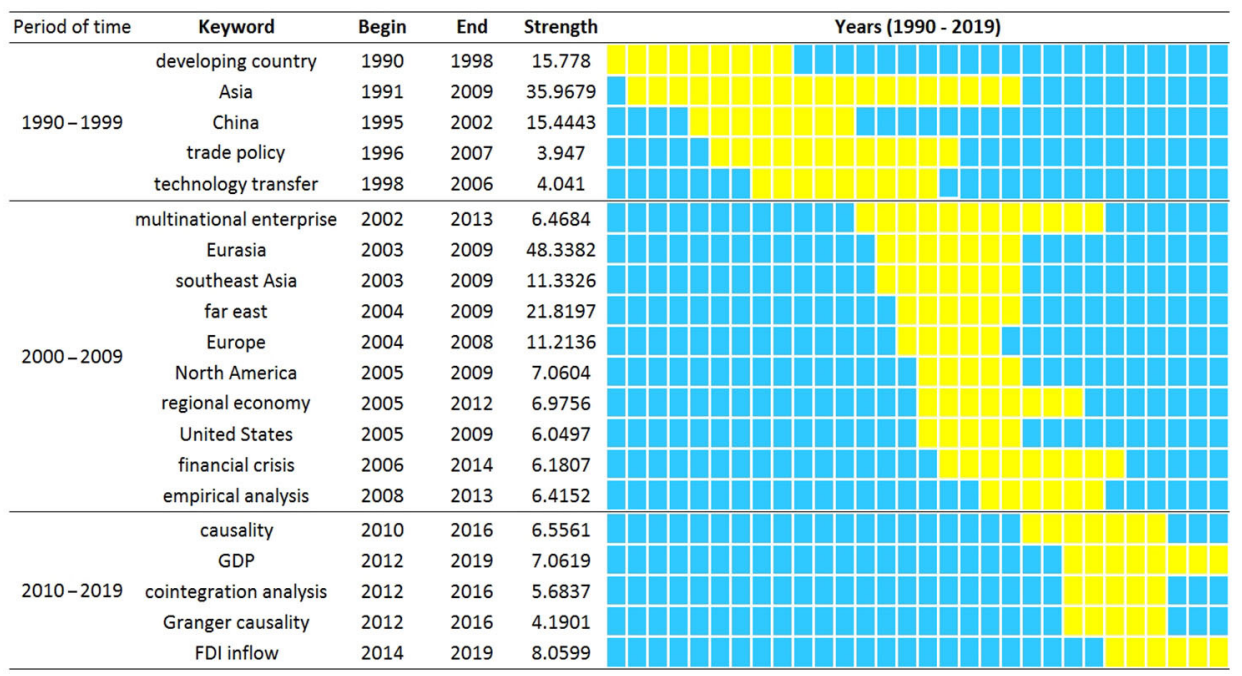

Figure 7. Top keywords with citation burst between 1990-2019

(source: Scopus, using Citespace) 
("China”, with a strength value of 15.4443), this fact shows us that the relationship between foreign direct investment and economic growth was stronger on the Asian continent, particularly in the far east (indeed, in the last 30 years, the highest rate of economic growth, based on foreign direct investment was on the Asian continent, especially in China; also, as we previously mentioned, the Asian continent is ranking number 1 in top continents for scientific production, according to the country of the corresponding author).

\section{Conclusions}

Following the bibliometric analysis on the 2289 documents we can conclude that the relationship between "economic growth" and "foreign direct investment" is a very strong one. This is illustrated by the fact that both terms are grouped within the same cluster (the red one), having a link strength with a value of 759, the largest of all links. Undoubtedly, the grouping of the two keywords within the same cluster is largely due to the way in which the collection of documents was carried out; in other words, it is logical that if the search was made for the keywords "economic growth" and "foreign direct investment", the connection between the two should be very strong. However, this cannot fully explain this grouping in the same cluster (as well as the strength of the link), as long as there are situations where the keywords in the initial database query are grouped into different clusters.

Regarding the temporal distribution of scientific output in the field, it should be noted that up to 1985 there was virtually no interest in studying the relationship between "foreign direct investment" and "economic growth". Later, this interest began to grow (especially from the beginning of the third millennium), reaching a scientific output of 324 documents. Regarding the geographical distribution, we can point it out that Asia is the leading continent regarding the scientific production (907 documents - articles, conference proceedings and book chapters), far away from the second place (Europe, with less than half - 406 documents).

Analyzing the semantic dimension of scientific production, the present study identifies that the attention of the authors in the field has focused on 3 main directions. The first direction considered the study of the relationship between "foreign direct investment" and "economic growth" from an economic perspective (with emphasis on econometrics aspects); the second direction focused on the ecological side of the relationship between the two phrases while the third direction considered the causal relationship between the phrases.

Finally, using Citespace, the authors can identify some "milestones" in the field of the relationship between foreign direct investment and economic growth, according to their citation burst. Also, the present study discovers a connection between the economic reality and the findings of the research in a way that the geographic region with the highest growth rate in the last 30 years (Asian continent, particularly China) was also reflected in the keyword citation burst.

The most important practical implication of this paper refers to the decision makers (governmental or non-governmental, public or private companies, agencies etc.) who carry out / finance / support foreign direct investments process. Thus, whether we are talking about an economy that exports investment to another country or is the beneficiary of foreign direct investment, the actors involved in the investment process (private companies, government 
agencies, large corporations, SME's) must understand that the process can no longer be carried out only on economic criteria (in order to obtain profit, respectively economic growth). As environmental problems, unprecedented pollution and climate change intensifies, economic decision-makers must also take into account environmental issues and its protection. Indeed, based on the analysis conducted in this research over the years, the attention of the authors has migrated from the purely economic aspects (for example, at the level of the year 2000, frequently used keywords were "manufacturing", "economic impact", "growth rate", "spillover effect") towards aspects related to ecology and environmental protection (after year 2015, keywords such as "pollution", "environmental economics" etc. can be found).

Therefore, this research can be continued in the future based on a study that highlights the relationship between "foreign direct investment" and "green economy" (which ensures environmental protection). Even if the analysis will be based on a less developed scientific literature (compared to "economic growth"), the concept of "green economy" represents the future solution for one of the most important problem of the mankind, namely environmental protection.

The present study cannot be finalized without illustrating the main limitations of the research. The first one refers to the selection of the analyzed scientific knowledge database. From this point of view, this is limited, using the Scopus database. Other databases (e.g. Web of Science) may contain other relevant papers in the field, which may bring additional information to the conducted research. The second limitation of this paper refers to the fact that only the titles, abstracts and keywords were taken into account for the analysis (the entire text of an article / conference paper / book chapter was not analyzed, as a whole). Taking into account this limitation, it is possible (using other software - Nvivo, QDAMiner etc.) to obtain some other results and conclusions, more or less far from those presented in the present study.

\section{Funding}

This work is financed according to OMEC no. 3132 / 2020 (Order of the Minister of Education and Research from Romania) for financing special situations, within the Project FSS Shanghai / 2020.

\section{Author contributions}

Within this paper, mr. Claudiu Cicea was responsible with the introduction section, Literature review, Research method and part of the "Results and Discussion" section (Scopus analysis and VOSViewer software). Mrs. Corina Marinescu was responsible for a part of the "Results and Discussion" section (Citespace software) and "Conclusions". Also, mrs. Corina Marinescu wrote the first form of the draft for the paper.

\section{Disclosure statement}

The authors declare that they have not any competing financial, professional or personal interests from other parties. 


\section{References}

Abdouli, M., \& Hammami, S. (2017). Investigating the causality links between environmental quality, foreign direct investment and economic growth in MENA countries. International Business Review, 26(2), 264-278. https://doi.org/10.1016/j.ibusrev.2016.07.004

Adam, S. (2009). Foreign Direct investment, domestic investment, and economic growth in Sub-Saharan Africa. Journal of Policy Modeling, 31(6), 939-949. https://doi.org/10.1016/j.jpolmod.2009.03.003

Alfaro, L., Chanda, A., Ozcan, S. K., \& Sayek, S. (2004). FDI and economic growth: the role of local financial markets. Journal of International Economics, 64(1), 89-112. https://doi.org/10.1016/S0022-1996(03)00081-3

Ali, U., Shan, W., Wang, J. J., \& Amin, A. (2018). Outward foreign direct investment and economic growth in china: evidence from asymmetric ARDL approach. Journal of Business Economics and Management, 19(5), 706-721. https://doi.org/10.3846/jbem.2018.6263

Artinok, H., \& Arslan, M. O. (2020). The relation between public expenditures and economic growth in Southeastern European countries: An analysis of bootstrap panel Granger causality. Economic Computation and Economic Cybernetics Studies and Research, 54(3), 249-262.

https://doi.org/10.24818/18423264/54.3.20.15

Azman Saini, W. N. W., Baharumshah, A. Z., \& Law, S. H. (2010). Foreign direct investment, economic freedom and economic growth: International evidence. Economic Modelling, 27(5), 1079-1089. https://doi.org/10.1016/j.econmod.2010.04.001

Bakhsh, K., Rose, S., Ali, M. F., Ahmad, N., \& Shahbaz, M. (2017). Economic growth, $\mathrm{CO}_{2}$ emissions, renewable waste and FDI relation in Pakistan: New evidences from 3SLS. Journal of Environmental Management, 196, 627-632. https://doi.org/10.1016/j.jenvman.2017.03.029

Balasubramanyam, V. N., Salisu, M., \& Sapsford, D. (1996). Foreign direct investment and growth in EP and is countries. The Economic Journal, 106(434), 92-105. https://doi.org/10.2307/2234933

Bende Nabende, A., Ford, J. L., \& Slater, J. R. (2000). The impact of FDI on the economic growth of the ASEAN-5 economies, 1970-94: A comparative dynamic multiplier analysis from a small model, with emphasis on liberalization. In J. L. Ford, (Ed.), Finance, governance and economic performance in Pacific and South East Asia (pp. 306-347). Edward Elgar.

Billas, V. (2020). FDI and economic growth in EU13 countries: Cointegration and causality tests. Journal of Competitiveness, 12(3), 47-63. https://doi.org/10.7441/joc.2020.03.03

Borensztein, E., De Gregorio, J., \& Lee, W. (1998). How does foreign direct investment affect economic growth? Journal of International Economics, 45(1), 115-135. https://doi.org/10.1016/S0022-1996(97)00033-0

Botha, I., Botezatu, M. A., \& Coanca, M. (2020). Innovative calculation model for evaluating regional sustainable development. Economic Computation and Economic Cybernetics Studies and Research, 54(3), 5-24. https://doi.org/10.24818/18423264/54.3.20.01

Bruhn, N. C. P., Alcantara, J. N., Tinelli, D. F., Reis, R. P., \& Antonialli, L. M. (2016). Why firms invest abroad? A bibliometric study on OFDI determinants from developing economies. Global Business Review, 17(2), 271-302. https://doi.org/10.1177/0972150915619802

Buitrago, M. L. M., \& Leon, J. M. G. (2015). Effects of foreign direct investment on economic growth in Colombia: Empirical evidence 2000-2010. Apuntes del Cenes, 34(59), 63-92. https://doi.org/10.19053/22565779.3536

Carbonell, J. B., \& Werner, R. A. (2018). Does foreign direct investment generate economic growth? A new empirical approach applied to Spain. Economic Geography, 94(4), 425-456. https://doi.org/10.1080/00130095.2017.1393312

Chaudhary, N. (2018). Foreign direct investment and economic growth in India. Pacific Business Review International, 10(12), 113-118. 
Chen, C. (2006). CiteSpace II: Detecting and visualizing emerging trends and transient patterns in scientific literature. Journal of the American Society for Information Science and Technology, 57(3), 359-377.

Chen, C. (2020). CiteSpace (version 5.6.R5) [Computer software]. http://cluster.cis.drexel.edu/ cchen/ citespace/

Cicea, C. (2020). Mapping the research agenda of Energy in urban area: A bibliometric analysis. Theoretical and Empirical Researches in Urban Management, 15(2), 66-80.

Cicea, C., Popa, I., Marinescu, C., \& Stefan, S. C. (2019). Determinants of SMEs' performance: Evidence from European countries. Economic Research-Ekonomska Istrazivanja, 32(1), 1602-1620. https://doi.org/10.1080/1331677X.2019.1636699

Cicea, C., Subic, J., \& Turlea, C. (2010). Specific economic efficiency indicators of investments in agriculture. Journal of Central European Agriculture, 11(3), 255-264.

De Andrade, A. G., \& Quing, Y. (2015). The role of foreign direct investment on economic growth. In Proceedings of the $12^{\text {th }}$ International Conference on Innovation and Management (pp. 1110-1114).

Dekker, E. (2020). Innovation commons: The origin of economic growth. Journal of Cultural Economics, 44(4), 663-664. https://doi.org/10.1007/s10824-020-09392-2

Diaconeasa, M. C., Popescu, G., \& Boboc, D. (2019). Sustainable food consumption in the Web of science abstracts. Economic Computation and Economic Cybernetics Studies and Research, 53(1), 299-307. https://doi.org/10.24818/18423264/53.1.19.19

Dong, Y., \& Fan, C. J. (2020). The role of China's aid and ODI in the economic growth of African countries. Emerging Market Review, 44, 100713. https://doi.org/10.1016/j.ememar.2020.100713

Dylewski, R., \& Adamczyk, J. (2012). Economic and ecological indicators for thermal insulating building investments. Energy and Buildings, 54, 88-95. https://doi.org/10.1016/j.enbuild.2012.07.021

Furková, A. (2012). Does foreign direct investment affect economic growth? Evidence from OECD countries. In Proceedings of the International Conference Quantitative Methods in Economics. Multiple criteria decision making XVI (pp. 56-61).

Gunby, P., Jin, Y. H., \& Reed, W. R. (2017). Did FDI really cause Chinese economic growth? A MetaAnalysis. World Development, 90, 242-255. https://doi.org/10.1016/j.worlddev.2016.10.001

Hagan, E., \& Amoah, A. (2020). Foreign direct investment and economic growth nexus in Africa New evidence from the new financial fragility measure. African Journal of Economic and Management Studies, 11(1), 1-17. https://doi.org/10.1108/AJEMS-05-2019-0180

Hakimi, A., \& Hamdi, H. (2016). Trade liberalization, FDI inflows, environmental quality and economic growth: A comparative analysis between Tunisia and Morocco. Renewable and Sustainable Energy Reviews, 58, 1445-1456. https://doi.org/10.1016/j.rser.2015.12.280

Hermes, N., \& Lensink, R. (2003). Foreign direct investment, financial development and economic growth. Journal of Development Studies, 40(1), 142-163. https://doi.org/10.1080/00220380412331293707

Hlavacek, P., \& Bal Domanska, B. (2016). Impact of foreign direct investment on economic growth in Central and Eastern European countries. Inzinerine Ekonomika-Engineering Economics, 27(3), 294-303. https://doi.org/10.5755/j01.ee.27.3.3914

Hochsteim, A. (2019). The investment multiplier: A comparison of three alternative approaches. International Advances in Economic Research, 25(3), 365-366.

https://doi.org/10.1007/s11294-019-09738-3

Hussain, M. E., \& Haque, M. (2016). Foreign direct investment, trade, and economic growth: An empirical analysis of Bangladesh. Economies, 4(2), 7. https://doi.org/10.3390/economies4020007

Iamsiraroj, S. (2016). The foreign direct investment-economic growth nexus. International Review of Economics \& Finance, 42, 116-133. https://doi.org/10.1016/j.iref.2015.10.044 
Iamsiraroj, S., \& Ulubasoglu, M. A. (2015). Foreign direct investment and economic growth: A real relationship or wishful thinking? Economic Modelling, 51, 200-213.

https://doi.org/10.1016/j.econmod.2015.08.009

Ketteni, E., Kottaridi, C., \& Mamuneas, T. P. (2015). Information and communication technology and foreign direct investment: Interactions and contributions to economic growth. Empirical Economics, 48(4), 1525-1539. https://doi.org/10.1007/s00181-014-0839-1

Keynes, J. M. (1936). The general theory of employment interest and money. Palgrave Macmillan Publishing House.

Khamphengvong, V., Xia, E., \& Srithilat, K. (2017, July). The relationship among FDI, trade openness and economic growth: Empirical evidence from Lao PDR. In $4^{\text {th }}$ International Conference on Industrial Economics System and Industrial Security Engineering (IEIS) (pp. 1-6). Kyoto, Japan. https://doi.org/10.1109/IEIS.2017.8078623

Kivyiro, P., \& Arminen, H. (2014). Carbon dioxide emissions, energy consumption, economic growth, and foreign direct investment: Causality analysis for Sub-Saharan Africa. Energy Journal, 74, 595606. https://doi.org/10.1016/j.energy.2014.07.025

Kondyan, S., \& Yenokyan, K. (2019). The effect of foreign direct investment on economic growth. Eastern Economic Journal, 45(4), 532-564. https://doi.org/10.1057/s41302-019-00140-9

Kumari, A., \& Kumar Sharma, A. (2017). Infrastructure financing and development: A bibliometric review. International Journal of Critical Infrastructure Protection, 16, 49-65. https://doi.org/10.1016/j.ijcip.2016.11.005

Kumari, A., \& Sharma, A. K. (2018). Causal relationship among electricity consumption, foreign direct investment and economic growth in India. Electric Journal, 31(7), 33-38. https://doi.org/10.1016/j.tej.2018.08.004

Lacko, R., Hajduova, Z., \& Pavolova, H. (2017). Efficiency of mining and quarrying industry of V4 countries: The impact of investments and selected indicators. Acta Montanistica Slovaca, 22(2), $136-145$.

Le, T. H., Chang, Y., \& Park, D. (2020). Renewable and nonrenewable energy consumption, economic growth, and emissions: International evidence. Energy Journal, 41(2), 73-92. https://doi.org/10.5547/01956574.41.2.thle

Lee, J. W. (2013). The contribution of foreign direct investment to clean energy use, carbon emissions and economic growth. Energy Policy, 55, 483-489. https://doi.org/10.1016/j.enpol.2012.12.039

Li, X., \& Liu, X. (2005). Foreign direct investment and economic growth: An increasingly endogenous relationship. World Development, 33(3), 393-407. https://doi.org/10.1016/j.worlddev.2004.11.001

Liesbeth, C., Maertens, M., \& Swinnen, J. (2009). Foreign direct investment as an engine for economic growth and human development: A review of the arguments and empirical evidence. Human Rights and International Legal Discourse, 3, 177-227.

Liu, X. H., Shu, C., \& Sinclair, P. (2009). Trade, foreign direct investment and economic growth in Asian economies. Applied Economics, 41(13), 1603-1612. https://doi.org/10.1080/00036840701579176

Ma, J., \& Jia, H. (2015). The role of foreign direct investment on income convergence in China after early 1990s from a spatial econometric perspective. Review of Development Economics, 19(4), 829-842. https://doi.org/10.1111/rode.12187

Makiela, K., \& Ouattara, B. (2018). Foreign direct investment and economic growth: Exploring the transmission channels. Economic Modelling, 72, 296-305. https://doi.org/10.1016/j.econmod.2018.02.007

Marinescu, C., Cicea, C., \& Colesca, S. (2019). Tracking biofuels-innovation relationship through scientific and technological advances. Management Research and Practice, 11(2), 31-44.

Mawugnon, A. K., \& Qiang, F. (2011). The relationship between foreign direct investment and economic growth in Togo [1991-2009]. In Proceedings of the $8^{\text {th }}$ International Conference on Innovation \& Management (pp. 1269-1273). 
Medne, Z. (2006). Foreign direct investment and economic growth in new EU Member States. In Jean Monet Conference "European Union enlargement of 2004 and beyond: Responding to the political, legal and socio-economic challenges". https://www.lu.lv/jmconference2006/dokumenti/Papers/ Zane_Medne.pdf

Mencinger, J. (2003). Does foreign direct investment always enhance economic growth? Kyklos Journal, 56(4), 491-508. https://doi.org/10.1046/j.0023-5962.2003.00235.x

Nestico, A., \& Maselli, G. (2020). Sustainability indicators for the economic evaluation of tourism investments on islands. Journal of Cleaner Production, 248, 119217. https://doi.org/10.1016/j.jclepro.2019.119217

Nwaogu, U. G., \& Ryan, M. J. (2015). FDI, Foreign aid, remittance and economic growth in developing countries. Review of Development Economics, 19(1), 100-115. https://doi.org/10.1111/rode.12130

Obando, H. R., \& Franco, L. D. R. (2017). Impact of foreign direct investment and openness degree on economic growth for Latin America 1980-2010. Estudios De Economia Aplicada, 35(1), 217-244.

Obsiannikova, T., Rabtsevich, O., \& Yugova, I. (2017). Evaluation of multiplier effect of housing investments in the city economy. Youth, Science, Solutions: Ideas and Prospects (YSSIP-2016). AIP Conference Proceedings, 1800(1), 050001. https://doi.org/10.1063/1.4973061

Olczyk, M. (2016). Bibliometric approach to tracking the concept of international competitiveness. Journal of Business Economics and Management, 17(6), 945-959. https://doi.org/10.3846/16111699.2016.1236035

Olofsdotter, K. (1998). Foreign direct investment, country capabilities and economic growth. Weltwirtschaftliches Archiv-Review of World Economics, 134(3), 534-537. https://doi.org/10.1007/BF02707929

Osei, M. J., \& Kim, C. J. (2020). Foreign direct investment and economic growth: Is more financial development better? Economic Modelling, 93, 154-161. https://doi.org/10.1016/j.econmod.2020.07.009

Otchere, L., Soumare, I., \& Yourougou, P. (2016). FDI and financial market development in Africa. World Economy, 39(5), 651-678. https://doi.org/10.1111/twec.12277

Paperpile. (n.d.). Research and writing guides. Retrieved March 28, 2020, from https://paperpile.com/g/ academic-research-databases/

Park, S. D. (2018). The nexus of FDI, R\&D and human capital on Chinese sustainable development: Evidence from a two-step approach. Sustainability, 10(6), 2063. https://doi.org/10.3390/su10062063

Salahuddin, M., Alam, K., Ozturk, I., \& Sohag, K. (2018). The effects of electricity consumption, economic growth, financial development and foreign direct investment on $\mathrm{CO}_{2}$ emissions in Kuwait. Renewable and Sustainable Energy Reviews, 81(Part 2), 2002-2010. https://doi.org/10.1016/j.rser.2017.06.009

Sapkota, P., \& Bastola, U. (2017). Foreign direct investment, income and environmental pollution in developing countries: Panel data analysis of Latin America. Energy Economics, 64, 206-212. https://doi.org/10.1016/j.eneco.2017.04.001

Sayari, N., Sari, R., \& Hammoudeh, S. (2018). The impact of value added components of GDP and FDI on economic freedom in Europe. Economic Systems, 42(2), 282-294.

https://doi.org/10.1016/j.ecosys.2017.03.003

Simionescu, M., \& Naros, M. S. (2019). The role of foreign direct investment in human capital formation for a competitive lobour market. Management Research and Practice, 11(1), 5-14.

Solarin, S. A., \& Shahbaz, M. (2015). Natural gas consumption and economic growth: The role of foreign direct investment, capital formation and trade openness in Malaysia. Renewable and Sustainable Energy Reviews, 42, 835-845. https://doi.org/10.1016/j.rser.2014.10.075

Soumare, I. (2015). Does FDI improve economic development in North African countries? Applied Economics, 47(51), 5510-5533. https://doi.org/10.1080/00036846.2015.1051655 
Soumare, I., \& Tchana, F. T. (2015). Causality and external validity: Causality between FDI and financial market development: Evidence from emerging markets. World Bank Economic Review, 29(Suppl 1), S205-S2016. https://doi.org/10.1093/wber/lhv015

Su, Y. O., \& Liu, Z. Q. (2016). The impact of foreign direct investment and human capital on economic growth: Evidence from Chinese cities. China Economic Review, 37, 97-109. https://doi.org/10.1016/j.chieco.2015.12.007

Tang, C. F., \& Tan, B. W. (2015). The impact of energy consumption, income and foreign direct investment on carbon dioxide emissions in Vietnam. Energy, 79(C), 447-454. https://doi.org/10.1016/j.energy.2014.11.033

Topcu, E., Altinoz, B., \& Aslan, A. (2020). Global evidence from the link between economic growth, natural resources, energy consumption and gross capital formation? Resources Policy, 66, 101622. https://doi.org/10.1016/j.resourpol.2020.101622

Torabi, G. (2015). Foreign direct investment and human development: The law and economics of international investment agreements. Journal of Human Development and Capabilities, 16(2), 316-317. https://doi.org/10.1080/19452829.2015.1028813

Van Eck, N. J., \& Waltman, L. (2019). VOSviewer (version 1.6.13) [Computer software]. Centre for Science and Technology Studies, Leiden University. https://www.vosviewer.com/

Van Eck, N. J., \& Waltman, L. (2011). Text mining and visualization using VOSviewer. ISSI Newsletter, $7(3), 50-54$.

Vekic, A., Djakovic, V., Borocki, J., Sroka, W., Popp, J., \& Olah, J. (2020). The importance of academic new ventures for sustainable regional development. Amfiteatru Economic, 22(54), 533-550. https://doi.org/10.24818/EA/2020/54/533

Vijayalakshmi, R., Palanisingh, V., Lingavel, G., \& Gurumoorthy, T. R. (2019). Factors determining in foreign direct investment (FDI) in India. International Journal of Recent Technology and Engineering, 8(2), 722-729. https://doi.org/10.35940/ijrte.B1129.0982S1019

Yulek, M., \& Gur, N. (2017). Foreign direct investment, smart policies and economic growth. Progress in Development Studies, 17(3), 245-256. https://doi.org/10.1177/1464993417713272

Zhang, Y., \& Zhang, S. F, (2018). The impacts of GDP, trade structure, exchange rate and FDI inflows on China's carbon emissions. Energy Policy, 120, 347-353. https://doi.org/10.1016/j.enpol.2018.05.056

Zhao, D. J., \& Gao, X. F. (2005). Multiplier effects of sport investment on economic growth. In Proceedings of $2^{\text {nd }}$ International Conference on Innovation \& Management (pp. 136-138). Wuhan, China.

Zhu, H. M., Duan, L. J., Guo, Y. W., \& Yu, K. M. (2016). The effects of FDI, economic growth and energy consumption on carbon emissions in ASEAN-5: Evidence from panel quantile regression. Economic Modelling, 58, 237-248. https://doi.org/10.1016/j.econmod.2016.05.003 


\section{APPENDIX}

Short history of FDI and economic growth relationship (source: author own conception)

\begin{tabular}{|c|c|c|}
\hline Continent & $\begin{array}{l}\text { (Authors, year) } \\
\text { (country) }\end{array}$ & Topic \\
\hline \multirow{10}{*}{ Europe } & $\begin{array}{l}\text { (Olofsdotter, 1998) } \\
\text { (Sweden) }\end{array}$ & $\begin{array}{l}\text { Relationship between GDP per capita (as a dependent variable) } \\
\text { and capital investment, population, technology gap, rate of } \\
\text { growth for foreign direct investment. }\end{array}$ \\
\hline & $\begin{array}{l}\text { (Mencinger, 2003) } \\
\text { (Slovenia) }\end{array}$ & $\begin{array}{l}\text { The paper studies the relationship between Foreign direct } \\
\text { investment and economic growth in eight transition countries, } \\
\text { for a period of } 7 \text { years (between } 1994 \text { and 2001). }\end{array}$ \\
\hline & $\begin{array}{l}\text { (Medne, 2006) } \\
\text { (Latvia) }\end{array}$ & $\begin{array}{l}\text { The paper analyse the relationship between economic growth } \\
\text { and foreign direct investment for the new members states of the } \\
\text { European Union. }\end{array}$ \\
\hline & $\begin{array}{l}\text { (Furková, 2012) } \\
\text { (Slovakia) }\end{array}$ & $\begin{array}{l}\text { The paper use stochastic model and data regarding the } \\
\text { employment within the OECD countries to study the } \\
\text { relationship between economic growth (measured by the rate of } \\
\text { growth for GDP) and foreign direct investment. }\end{array}$ \\
\hline & $\begin{array}{l}\text { (Hlavacek \& Bal } \\
\text { Domanska, 2016) } \\
\text { (Czech Republic) }\end{array}$ & $\begin{array}{l}\text { The paper analyzes the impact of foreign direct investment } \\
\text { on economic growth in Central and East European countries } \\
\text { (Czech Republic, Slovenia, Slovakia, Estonia, Hungary, Latvia, } \\
\text { Poland and Lithuania). }\end{array}$ \\
\hline & $\begin{array}{l}\text { (Yulek \& Gur, 2017) } \\
\text { (Turkey) }\end{array}$ & $\begin{array}{l}\text { Foreign direct investments, besides their well-known benefits, } \\
\text { require a cost which, in some cases, represents an important } \\
\text { issue. }\end{array}$ \\
\hline & $\begin{array}{l}\text { (Makiela \& Ouattara, } \\
\text { 2018) } \\
\text { (United Kingdom) }\end{array}$ & $\begin{array}{l}\text { Using data over a period of } 37 \text { years (between } 1970 \text { and 2007), } \\
\text { the paper analyzes the relationship between foreign direct } \\
\text { investment and economic growth, concluding that there are } \\
\text { also other factors that contribute to productivity and economic } \\
\text { growth. }\end{array}$ \\
\hline & $\begin{array}{l}\text { (Carbonell \& } \\
\text { Werner, 2018) } \\
\text { (Spain) }\end{array}$ & $\begin{array}{l}\text { Over a period of } 26 \text { years (1984-2010), the study analyzes the } \\
\text { influence of foreign direct investment on economic growth } \\
\text { in a single country (Spain), concluding that there are other } \\
\text { important factors that determine GDP growth. }\end{array}$ \\
\hline & $\begin{array}{l}\text { (Ketteni et al., 2015) } \\
\text { (Cyprus) }\end{array}$ & $\begin{array}{l}\text { The paper analyzes the combined effect of domestic capital } \\
\text { stock and foreign direct investment on economic growth and } \\
\text { productivity for } 15 \text { OECD member countries. }\end{array}$ \\
\hline & $\begin{array}{l}\text { (Sayari et al., 2018) } \\
\text { (Turkey) }\end{array}$ & $\begin{array}{l}\text { The study examines the existence of a potential long-term } \\
\text { relationship between Foreign Direct Investment, the Economic } \\
\text { Freedom Index and value added components of GDP. }\end{array}$ \\
\hline \multirow{3}{*}{ Asia } & $\begin{array}{l}\text { (Bende et al., 2000) } \\
\text { (Thailand) }\end{array}$ & $\begin{array}{l}\text { Econometric perspective regarding the role of foreign direct } \\
\text { investment on the economic growth within Asian countries, for } \\
\text { a period of } 24 \text { years (between } 1970 \text { and 1994). }\end{array}$ \\
\hline & $\begin{array}{l}\text { (Liu et al., 2009) } \\
\text { (Hong Kong) }\end{array}$ & $\begin{array}{l}\text { The paper is dealing with the casual connection between trade, } \\
\text { economic growth and foreign direct investments; the analysis is } \\
\text { conducted within Asian economies. }\end{array}$ \\
\hline & $\begin{array}{l}\text { (Azman et al., 2010) } \\
\text { (Malaysia) }\end{array}$ & $\begin{array}{l}\text { The paper analyzes the connection between economic freedom, } \\
\text { economic growth and foreign direct investment within } 85 \\
\text { countries. }\end{array}$ \\
\hline
\end{tabular}


Continued Appendix Table

\begin{tabular}{|c|c|c|}
\hline Continent & $\begin{array}{l}\text { (Authors, year) } \\
\text { (country) }\end{array}$ & Topic \\
\hline & $\begin{array}{l}\text { (Kondyan \& } \\
\text { Yenokyan, 2019) } \\
\text { (Kazakhstan) }\end{array}$ & $\begin{array}{l}\text { The paper presents a theoretical model that studies the effects } \\
\text { of Foreign direct investment on the economic growth in special } \\
\text { conditions, in the absence of channels through which the } \\
\text { spillover effects of FDI operate; therefore, the model illustrates } \\
\text { how FDI affects economic growth through its primary function } \\
\text { of capital accumulation. }\end{array}$ \\
\hline & $\begin{array}{l}\text { (Solarin \& Shahbaz, } \\
\text { 2015) } \\
\text { (Pakistan) }\end{array}$ & $\begin{array}{l}\text { The paper analyzes the relationship between gas consumption } \\
\text { and economic growth based on the consideration of foreign } \\
\text { direct investment, freedom of trade and capital in Malaysia, for } \\
\text { the period 1971-2012. }\end{array}$ \\
\hline & $\begin{array}{l}\text { (Ma \& Jia, 2015) } \\
\text { (China) }\end{array}$ & $\begin{array}{l}\text { Using panel data over the period 1991-2007, the paper } \\
\text { investigates the impact of foreign direct investment as an } \\
\text { endogenous variable on income in China. }\end{array}$ \\
\hline & $\begin{array}{l}\text { (Su \& Liu, 2016) } \\
\text { (China) }\end{array}$ & $\begin{array}{l}\text { The study considers the analysis of the determinants of } \\
\text { economic growth, with a focus on foreign direct investments } \\
\text { and human resources, using Solow's model. }\end{array}$ \\
\hline & $\begin{array}{l}\text { (Zhu et al., 2016) } \\
\text { China }\end{array}$ & $\begin{array}{l}\text { The paper analyzes the impact of economic growth, energy } \\
\text { consumption and foreign direct investment on carbon emissions } \\
\text { for } 5 \text { countries in Southeast Asia (Indonesia, Malaysia, } \\
\text { Philippines, Singapore and Thailand). }\end{array}$ \\
\hline & $\begin{array}{l}\text { (Bakhsh et al., 2017) } \\
\text { (Pakistan) }\end{array}$ & $\begin{array}{l}\text { The paper analyzes from an econometric perspective the effects } \\
\text { that foreign direct investment has on environmental pollution } \\
\text { and economic growth in Pakistan. }\end{array}$ \\
\hline & $\begin{array}{l}\text { (Khamphengvong } \\
\text { et al., 2017) } \\
\text { (China) }\end{array}$ & $\begin{array}{l}\text { The study examines the long-term relationship between } \\
\text { economic growth, trade openness and foreign direct investment } \\
\text { in Lao PDR. }\end{array}$ \\
\hline & $\begin{array}{l}\text { (Kumari \& Sharma, } \\
\text { 2018) } \\
\text { (India) }\end{array}$ & $\begin{array}{l}\text { The analysis aims at the causal relationship between foreign } \\
\text { direct investment, gross domestic product and energy } \\
\text { consumption in India. }\end{array}$ \\
\hline & $\begin{array}{l}\text { (Zhang \& Zhang, } \\
\text { 2018) } \\
\text { (China) }\end{array}$ & $\begin{array}{l}\text { The study analyzes the influence of trade structure, exchange } \\
\text { rate, foreign direct investment and gross domestic product on } \\
\text { carbon emissions in China between 1982-2016. }\end{array}$ \\
\hline & $\begin{array}{l}\text { (Vijayalakshmi et al., } \\
2019) \\
\text { (India) }\end{array}$ & $\begin{array}{l}\text { The paper investigates the main determinants of foreign direct } \\
\text { investment for Indian economy. }\end{array}$ \\
\hline \multirow{3}{*}{$\begin{array}{l}\text { North } \\
\text { America }\end{array}$} & $\begin{array}{l}\text { (Nwaogu \& Ryan, } \\
\text { 2015) } \\
\text { (United States) }\end{array}$ & $\begin{array}{l}\text { The study examines the relationship between foreign aid, foreign } \\
\text { direct investment and economic growth, on a group of } 53 \\
\text { African countries and } 34 \text { countries in Latin America and the } \\
\text { Caribbean. }\end{array}$ \\
\hline & $\begin{array}{l}\text { (Soumare, 2015) } \\
\text { (Canada) }\end{array}$ & $\begin{array}{l}\text { The paper analyzes the relationship between foreign direct } \\
\text { investment flows on the level of well-being for North African } \\
\text { countries, taking into account the human development index as } \\
\text { an independent variable. }\end{array}$ \\
\hline & $\begin{array}{l}\text { (Soumare \& Tchana, } \\
\text { 2015) } \\
\text { (Canada) }\end{array}$ & $\begin{array}{l}\text { The paper analyzes the causal relationship between foreign } \\
\text { direct investment and financial market development in } \\
\text { emerging markets. }\end{array}$ \\
\hline
\end{tabular}


End of Appendix Table

\begin{tabular}{|c|c|c|}
\hline Continent & $\begin{array}{l}\text { (Authors, year) } \\
\text { (country) }\end{array}$ & Topic \\
\hline & $\begin{array}{l}\text { (Otchere et al., 2016) } \\
\text { (Canada) }\end{array}$ & $\begin{array}{l}\text { The study analyzes the relationship between financial market } \\
\text { development and foreign direct investment in the African } \\
\text { context. }\end{array}$ \\
\hline & $\begin{array}{l}\text { (Hussain \& Haque, } \\
\text { 2016) } \\
\text { (United States) }\end{array}$ & $\begin{array}{l}\text { Based on an analysis between } 1973 \text { and 2014, the study confirms } \\
\text { the existence of a relationship between trade, foreign direct } \\
\text { investment and growth rate of GDP per capita in Bangladesh. }\end{array}$ \\
\hline & $\begin{array}{l}\text { (Sapkota \& Bastola, } \\
\text { 2017) } \\
\text { (United States) }\end{array}$ & $\begin{array}{l}\text { The paper analyzes the link between foreign direct investment, } \\
\text { environmental pollution and economic growth, for } 14 \text { countries } \\
\text { in South America, during } 1980-2010 \text {. }\end{array}$ \\
\hline & $\begin{array}{l}\text { (Salahuddin et al., } \\
\text { 2018) } \\
\text { (Canada) }\end{array}$ & $\begin{array}{l}\text { Based on an econometric approach, the paper analyzes the } \\
\text { relationship between electricity consumption, foreign direct } \\
\text { investment, economic growth and financial development on } \\
\text { carbon emissions in Kuwait. }\end{array}$ \\
\hline \multirow{2}{*}{$\begin{array}{l}\text { South } \\
\text { America }\end{array}$} & $\begin{array}{l}\text { (Buitrago \& Leon, } \\
\text { 2015) } \\
\text { (Colombia) }\end{array}$ & $\begin{array}{l}\text { The paper analyzes the direct and indirect effects of foreign } \\
\text { direct investment on economic growth over a period of } 10 \text { years } \\
\text { (between 2000-2010) for Colombia. }\end{array}$ \\
\hline & $\begin{array}{l}\text { (Obando \& Franco, } \\
2017) \\
\text { (Colombia) }\end{array}$ & $\begin{array}{l}\text { The study analyzes foreign direct investment and openness } \\
\text { degree on economic growth for } 9 \text { Latin American countries, } \\
\text { between 1980-2010. }\end{array}$ \\
\hline \multirow{3}{*}{$\begin{array}{l}\text { Australia } \\
\text { \& New } \\
\text { Zealand }\end{array}$} & $\begin{array}{l}\text { (Iamsiraroj \& } \\
\text { Ulubasoglu, 2015) } \\
\text { (Australia) }\end{array}$ & $\begin{array}{l}\text { The paper addresses, from an econometric perspective, the } \\
\text { influence of foreign direct investment on economic growth, on a } \\
\text { group of } 140 \text { countries, in the period } 1970-2009 \text {. }\end{array}$ \\
\hline & $\begin{array}{l}\text { (Iamsiraroj, 2016) } \\
\text { (Australia) }\end{array}$ & $\begin{array}{l}\text { Econometric perspective of the relationship between foreign } \\
\text { direct investment and economic growth on } 124 \text { cross-country } \\
\text { data. }\end{array}$ \\
\hline & $\begin{array}{l}\text { (Gunby et al., 2017) } \\
\text { (New Zealand) }\end{array}$ & $\begin{array}{l}\text { The paper aims to investigate the role that foreign direct } \\
\text { investment has played on the Chinese economic "miracle". The } \\
\text { authors conclude that their role is exaggerated in the literature } \\
\text { and that the real causes of China's economic growth must be } \\
\text { sought elsewhere. }\end{array}$ \\
\hline \multirow{2}{*}{ Africa } & $\begin{array}{l}\text { (Hakimi \& Hamdi, } \\
2016) \\
\text { (Tunisia) }\end{array}$ & $\begin{array}{l}\text { Through a comparative approach between Morocco and Tunisia, } \\
\text { the paper analyzes the influence of trade liberalization and } \\
\text { foreign direct investment on the quality of the environment and } \\
\text { economic growth. }\end{array}$ \\
\hline & $\begin{array}{l}\text { (Abdouli \& } \\
\text { Hammami, 2017) } \\
\text { (Tunisia) }\end{array}$ & $\begin{array}{l}\text { Based on an econometric analysis, the paper studies the } \\
\text { causal relationship between environmental quality, economic } \\
\text { growth and foreign direct investment, on a group of } 17 \text { MENA } \\
\text { countries. }\end{array}$ \\
\hline
\end{tabular}

